\section{Storage of frozen sections in paraffin blocks}

\author{
E. K. AVES, G. R. N. JONES, and G. J. CUNNINGHAM \\ From the Department of Pathology, Royal College \\ of Surgeons of England, London
}

The development of the techniques for cutting frozen sections, in particular the use of cryostat microtomes (Pearse, 1960; Cunningham, Bitensky, Chayen, and Silcox, 1960 and 1962; Goodbody, 1963 a and b; Cunningham, 1963), has resulted in sections which not only are produced routinely very rapidly but which are completely acceptable histologically. Such sections would be ideal, especially where speed is important, were it not for the problems of storing and recutting the frozen tissue should it become necessary to refer to this material at a later time. The present communication describes a method by which frozen tissue, which has been used for cryostat microtomy, can be fixed and embedded in paraffin wax for indefinite storage.

\section{MATERIALS AND METHODS}

Unfixed human tissue, removed at operation and frozen, has been studied: normal breast tissue; breast and lymph node infiltrated by carcinoma; normal stomach; carcinoma of the stomach. Frozen specimens of spleen, kidney, pancreas, and liver of rats have also been investigated.

The tissue was frozen by the method of Cunningham et al. $(1960,1962)$ and sections were cut at $8 \mu$, by the use of a refrigerated microtome. The blocks of frozen tissue were removed from the object-holder and placed at $+4^{\circ} \mathrm{C}$. for one hour. They were then immediately immersed in formal-saline $(10 \%$ formalin in $0.85 \%$ aqueous sodium chloride solution) at room temperature for at least $\mathbf{2 4}$ hours. The fixed tissue was then dehydrated, cleared, and embedded either by hand or by the use of an Elliott automatic processer; this procedure did not appear to be critical. Sections were cut at $5 \mu$ and, after the wax was removed, they were stained with haematoxylin and eosin.

\section{RESULTS AND DISCUSSION}

For each specimen, the results obtained after this whole treatment (Figs. 1, 2, 3) were in every way comparable with those observed with similar tissues which had been fixed directly in formalin, without prior freezing. The complete lack of any sign of damage or altered response to the stains was surprising since other techniques involving simultaneous thawing and fixing of tissue had resulted in gross artefacts. Indeed, it was found that immersing the frozen blocks of tissue in warm formalinsaline at various temperatures, in an attempt to achieve very rapid thawing, proved disastrous to the tissues.

Received for publication 8 August 1964.

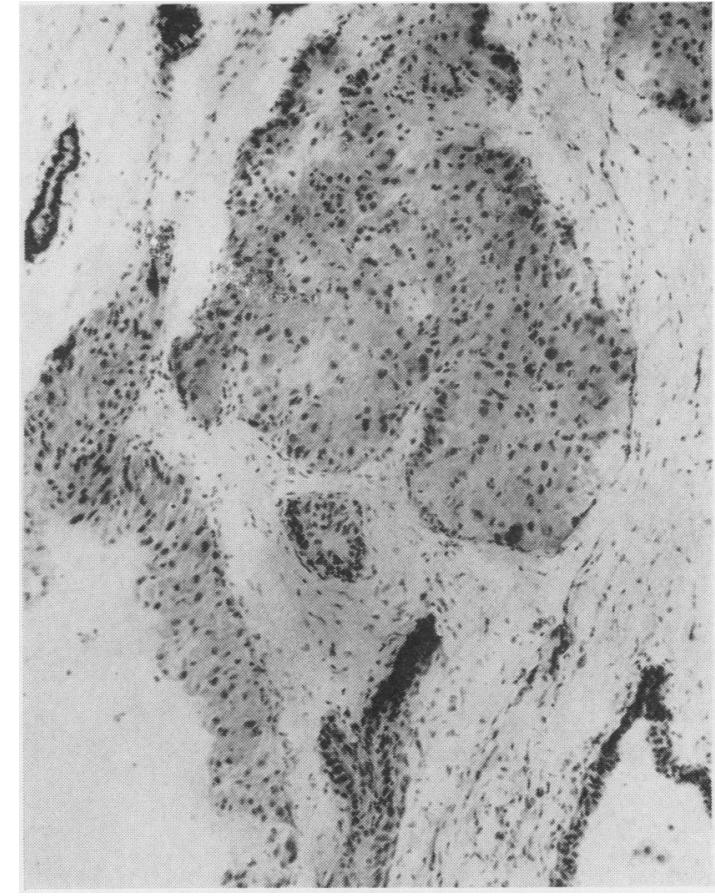

FIG. 1. Frozen carcinoma of breast. Haematoxylin and eosin, $\times 100$.



FIG. 2. Breast cut after conversion of frozen tissue to paraffin block. Haematoxylin and eosin, $\times 100$. 




FIG. 3. Carcinoma of breast infiltrating into lymph node, cut after conversion of frozen tissue to paraffin block. Haematoxylin and eosin, $\times 300$.

The fact that excellent sections can be easily prepared by the cryostat should do much to encourage the extended use of this method in the routine laboratory. The ability to treat such frozen tissue so that it can be stored and therefore available for future paraffin sectioning should assist in making 'frozen histology' more generally available.

We wish to thank Dr. S. J. Surtees for obtaining the specimens of human tissue, Dr. Lucille Bitensky for guidance, and Mr. A. L. E. Barron for the photography.

\section{REFERENCES}

Cunningham, G. J. (1963). Brit. med. J., 2, 562.

_-, Bitensky, L., Chayen, J., and Silcox, A. A. (1960). First international Congress of Histochemistry and Cytochemistry, Abstracts, p. 5. Pergamon Press, London. (1962). Ann. Histochim., 6, 433.

Goodbody, R. A. (1963a). Brit. med. J., 2, 53.

(1963b) . Ibid. 2, 869

Pearse, A. G. E. (1960). Histochemistry: Theoretical and Apptied, 2nd ed. Churchill, London.

\section{Simple method for the estimation of platelet adhesiveness}

E. A. CASPARY From the Medical Research Counci Research Group on Demyelinating Diseases, Royak Victoria Infirmary and University of Newcastle कै

Current means of estimating the adhesiveness of blood $\vec{P}$ platelets either utilize special equipment, such as standard glassware (Wright, 1941), complex motor-driven con尺 stant flow devices (Hellem, 1960), or else they do not define a constant contact area of glass (Moolten and Vroman, 1949; Hellem, 1960). The method describedo here is both simple and reliable.

Blood is taken by clean venepuncture from an ante cubital vein into sequestrene in plastic containers to give a final concentration of $4.5 \mathrm{mM}$. This anticoagulant? though it reduces the overall adhesiveness (Marx and Derlath, 1957), prevents non-specific clumping and pre? serves platelet morphology. With heparin results were a times difficult to assess owing to marked platelet clump $\vec{c}$ ing. The platelet-free plasma is prepared by centrifugationo at $2,000 \mathrm{~g}$ for 20 minutes. Siliconed bottles are first thoroughly cleaned in 'chromic acid,' washed in tap water? followed by distilled water. After oven drying they are given three coats of Repelcote (Hopkin and Williams Ltd.). Cover slips are cleaned in concentrated nitric acido washed clean of acid, and polished with alcohol.

The test is done by mixing $1.0 \mathrm{ml}$. of blood and $0.5 \mathrm{ml} \stackrel{\text { ? }}{2}$ of platelet-free plasma in each of two siliconed bottles, $\overrightarrow{\vec{B}}$ inserting a cover slip into one and shaking both bottles for $90^{1}$ minutes, either on a reciprocating shaker or rotating Matburn mixer. Platelet counts are taken bot $\vec{P}$. at the end of this period and adhesiveness calculated from the ratio of the control and experimental platelet counts? Ten of the 16 squares of a Neubauer chamber are counted on each side to give an overall cell count of 800 to 1,000 ? in cases of thrombocytopenia additional counting chambers are used to bring the overall number of cells counted into the stated range. No attempt was made too relate the adhesiveness to the initial blood platelet coun as even shaking or mixing in coated bottles for this periot of time can cause a drop in platelet count of $10 \%$ (Wright 1941) and even greater platelet losses occur with reciprocating mixers. The results obtained for a series of 12 normal individuals, ranging in age from 20 to 49 . varied between 91 and 78 (expressed as the percentagew of control count). Standard deviation of replicater determinations was $2 \%$.

${ }^{1}$ The time of 90 minutes was chosen because adhesion appears to be maximal around that period; however, results can be obtained infs
40 minutes or an hour.

\section{REFERENCES}

Hellem, A. J. (1960). The Adhesiveness of Human Blood Platelets in Vitro. Oslo University Press.

Marx, R., and Derlath, S. (1957). Blut, 3, 247.

Moolten, S. E., and Vroman, L. (1949). Amer. J. clin. Path., 19, 7010

Wright, H. P. (1941). J. Path. Bact., 53, 255.

Received for publication 22 July 1964. 